JKAU: Eng. Sci., Vol. 29 No. 1, pp: 3 - 19 (1439 A.H. / 2018 A.D.)

Doi: $10.4197 /$ Eng. 29-1.1

\title{
Utilizing Quality Tools: Enhance the Productivity at Aircraft Maintenance Sector of Saudi Airlines
}

\author{
Omar S. Barboud, Reda M. S. Abdulaal and Mohammad R. Kabli \\ Industrial Engineering Department, Faculty of Engineering ‘ King Abdulaziz University, Jeddah, \\ Saudi Arabia \\ o.barboud@hotmail.com
}

\begin{abstract}
The performance at Saudi airlines maintenance company has dropped last three years, which revealed by the indication of the technical On-Time Performance (OTP) of A330 fleet. Three types of technical delays played a big role for affecting the OTP. These delays can be categorized as mechanical delays, spare part delays and the human error delays. Therefore, this paper proposed a model that based on three quality control tools which are Pareto chart, P-chart, and Fishbone analysis. These tools are integrated together to improve the maintenance services by studying the root causes of the three technical delays. The Pareto chart used to highlight the aircraft subsystems that affecting the aircraft performance. Most of the delays subsystems were the landing gears, doors, cabin, fuel and flight controls. Then the control chart (P-Chart) showed the defected delays points fall out the upper control limit, which found three months need to put into consideration for evaluation and investigation. Then the application of the fishbone depended on the problems faced through the application of Pareto chart and P-chart tools. The proposed model applied in year 2017 and showed an increase in the technical OTP to reach $96.01 \%$ compared with $94.87 \%$ in year 2016. The A330 fleet utilization increased by $60.6 \%$ and the total revenue departure cycle increased by $51 \%$. The paper, also, pointed out recommendations and suggestions to the company to sustain its competitive advantages in the airlines business market.

Keywords: Quality Control Tools, On-Time Performance, Aircraft Maintenance, Technical Delays, Mechanical Delays.
\end{abstract}

\section{Introduction}

Under the observed expansion of airlines companies and the competition for attracting the passengers; many companies develop their facility to access the global competition in the markets, to improve their productivity, and to attract customers for using their products.

The maintenance sector at Saudi Airlines Company (SAUDIA) has the magnificent role and impact for either pretend the company improvement or degrading which effect on the airlines repetition. The statistics data reported by the reliability program department at SAUDIA found reduction on the On-Time Performance (OTP) for the A330 fleet in last 3 years. This reduction comes from delays in the work that must done by the maintenance sector at SAUDIA.

The aim of this paper is to increase the maintenance sector productivity which correspondingly will has a positive impact on increasing SAUDIA revenues. There are several ways to improve the maintenance sector productivity ${ }^{[1,2]}$. One of these ways is 
using the seven quality control tools, that commonly known as 7QC tools. The 7QC tools have the ability to identify and analyze the company's problems related to the maintenance process. Once the problems are identified and analyzed, the appropriate solutions can be obtained to increase the productivity.

The paper is organized as follows: The next section demonstrates principles of the total quality management (TQM) and the models commonly applied for quality control tools followed by analysis of the proposed model methodology, then implementation of the proposed quality control techniques including the data collection and the results obtained. Finally, provide the recommendations and suggestions for future studies.

\section{Principles of Total Quality Management (TQM)}

\subsection{Total Quality Management Tools}

Total Quality Management (TQM) tools are used to work in the quality tasks and commonly include statistical graphs and charts. TQM allows changing the ideology regarding the quality of department from the top-level management to lowest level workers. It makes administration to enhance the aversion than to inspect by actualizing a key way to deal with the quality. Through TQM, every employee is prepared with his expertise to urge and settle on all choices alone to enhance the general quality and accomplish higher benchmarks ${ }^{[3]}$. TQM follows eight principles, which can be defined as fundamentals or basic rules or an entire dogma for managing any organization. Below are the following eight principles of TQM:

- Customer Focus

- Process Approach

- System Approach to Management

- Mutually Beneficial Supplier Relationships
- Factual Approach to Decision Making

- Leadership

- Involvement of People

- Continual Improvement

\subsection{Quality Control Tools}

In organizations, a typical way of supervising the quality is the Quality Control (QC). It helps in checking and reviewing work that has been completed. To make sure that products and services meet the required criteria, Inspection is done and this process takes place during and at the end of the operation process. The QC is also defined as the administrative technique through which the genuine quality execution is measured, contrasted and compared with standard, at that point of following up on distinctions. It is an advanced management tool that targets to avert products and services that do not meet the basic requirements ${ }^{[4]}$.

There are seven quality control tools, which are commonly used for their simplicity in implementation and easy to understand ${ }^{[5]}$. These tools defined as the Total Quality Management (TQM) tools and can be titled as follows: (1) check sheet, (2) flow charts, (3) control charts, (4) cause-and-effect diagram(Fishbone), (5) scatter plot, (6) Pareto chart, and (7) histogram ${ }^{[6]}$.

\section{Literature Review}

\subsection{TQM Methods and Tools Improved the Aviation Companies}

TQM is a process that improves Aviation Company continuously and improves quality with management philosophy that accomplishes customers or clients for their satisfaction. Proper principle and management increase aviation company quality as well as reduce extensible cost. Below are examples of Airline companies present and overview study of elements, function, and methodologies of TQM and 
how it can be taken from theory and operationalized at aviation processes.

\section{- Indian Airlines}

Gupta and Belokar [7], Investigated Critical success factor for TQM Implementation in Indian airline industry in order to improve the performance and identify the main impediments of implementing TQM successfully. Based on the data collecting from the questionnaires, interviews and the obtained data from articles, journals and online resources, a T-test hypothesis was carried out to measure the difference in means of TQM airline and Non-TQM airlines in the areas of employee satisfaction, customers' satisfaction, and effective operations. The tests found that TQM has a great impact on the organizational performance. The results show in Tables 1, 2, and 3 confirm the theory that TQM organizations have competitive advantages in meeting customers and employees needs while also enabling the organization to be effective in their daily operations.

Table 1. Mean performance for employee satisfaction.

\begin{tabular}{|c|c|c|c|}
\hline Airlines & Total Mean & $\begin{array}{c}\text { Average } \\
\text { Mean }\end{array}$ & $\begin{array}{c}\text { Mean } \\
\text { Diff. }\end{array}$ \\
\hline TQM Airlines & 21.32 & 3.55 & \multirow{2}{*}{0.92} \\
\hline $\begin{array}{c}\text { Non-TQM } \\
\text { Airlines }\end{array}$ & 15.81 & 2.64 & \\
\hline
\end{tabular}

Table 2. Mean performance for customer satisfaction.

\begin{tabular}{|c|c|c|c|}
\hline Airlines & $\begin{array}{c}\text { Total } \\
\text { Mean }\end{array}$ & $\begin{array}{c}\text { Average } \\
\text { Mean }\end{array}$ & Mean Diff. \\
\hline TQM Airlines & 21.32 & 3.55 & \multirow{2}{*}{0.92} \\
\cline { 1 - 2 } $\begin{array}{c}\text { Non-TQM } \\
\text { Airlines }\end{array}$ & 15.81 & 2.64 & \\
\hline
\end{tabular}

Table 3. Mean Performance for Operational Effectiveness.

\begin{tabular}{|c|c|c|c|}
\hline Airlines & $\begin{array}{c}\text { Total } \\
\text { Mean }\end{array}$ & $\begin{array}{c}\text { Average } \\
\text { Mean }\end{array}$ & $\begin{array}{c}\text { Mean } \\
\text { Diff. }\end{array}$ \\
\hline TQM Airlines & 32.33 & 4.04 & \multirow{2}{*}{1.10} \\
\hline Non-TQM Airlines & 23.57 & 2.95 & \\
\hline
\end{tabular}

\section{- Etihad Airlines}

Etihad Airways is the national airline for United Arabian Emirate; The Company operates 88 aircrafts, with over 1400 flights weekly, and operates in a network of 84 destinations all over the world. Etihad Airways exercises a number of quality management practices as follows ${ }^{[8]}$ :

OThe TQM implementation in Etihad Airlines clearly found in the service reliability. It is able to offer air transport services in various destinations around the world. The company has received various awards such as the "World's Leading Airline" in 2013 because of its good reliability, Etihad Airways gains 5 stars on Skytrax rating in $2016^{\text {[9] }}$. In addition, the company displays responsiveness as it is able to help and be prompt in provision of service. It is able to offer flight service and prompt in the service response.

oEtihad Airways implements the quality management practices through its commitment to continuous improvement. For instance, the company adopted Intertek fuel quality testing practice to ensure top quality for the biofuels it uses in its aircrafts. The company is dedicated to achieving efficiency and reduction of errors, enhancing productivity, and achieving effectiveness in use of resources. However, Applying TQM reflects high growth on Etihad Airlines from 2010-2016 ${ }^{[10]}$ as shown in Table 4.

\subsection{Previous Studies of Quality Control Tools in Maintenance Sectors}

Most of previous studies have combined some of quality control tools in one application for analyzing the problem and to find the failures defect associated to solve the problems on maintenance sector. Therefore, the previous studies for the implement of 7QC tools presents the different kinds of tools contributed to enhance the productivity in maintenance sectors depends on the needed of the appropriate tools were selected. 
Montgomery ${ }^{[11]}$ described a successful statistical quality control tools application in a printed circuit board fabrication facility. The company decided to implement statistical QC tools after experiencing high levels of defects and extensive work backlogs. Successful application of cause-and-effect diagrams, check sheets, Pareto analysis, and an additional statistical technique known as design-of-experiments enabled the company to realize a reduction of work backlog and a reduction in the number of defective parts by a factor of 10 .

\section{The Proposed QC Tools Methodology}

The overall research strategy from data collection to the proposed quality control can be simply explained by the block diagram shown in figure 1 , which can be divided to eighteenth steps included the implementation of the Pareto chart, Control Chart and the Fishbone technique.

\subsection{Step (1): Data Collection}

Aircraft Reliability Program department at the Saudi Airlines company has their own program to collect the required data, which will be used here later. The data includes the flight hours, revenue dispatches, technical delays and aircraft cycle. Upon this information the OTP can be calculated for categorizing and segregating each of technical delays. The selected data is defined as the on-time performance, which refers to the level of success of the service. Choosing this data depends on the deviation that was indicated in the Saudi Aircraft fleet OTP records, especially the A330 fleet in which the OTP dropped off from February 2016 to January 2017.

\subsection{Steps (2-5): Data Analysis}

Data analysis on this paper consists of several steps aims to find the numerical data of OTP. The number of technical delays and the delays rates which can be calculated through step 2 to step 5 in Fig.1. Those data can be used to adopt the quality control tools by analyzing the OTP throughout the Pareto Chart, Control Chart and Fishbone.

Based on the data collected over six years (January 2011 till January 2017), the OTP can be calculated by using the following formula. Figure 5 shows part of the data collected for the duration from February 2016 till January 2017.

$$
\begin{aligned}
& \text { OTP }=100-\text { Dealys Rate }= \\
& 100-\frac{\text { Technincal delays }}{\text { Revenue Dapartures }} \times 100
\end{aligned}
$$

The collected technical OTP data is plotted in figure. 2 to demonstrate how the OTP has been dropped starting from January 2015.

Table 4. Etihad Airlines Trend from 2010 to 2016.

\begin{tabular}{|l|l|l|l|l|l|l|l|}
\hline Year/ Item & $\mathbf{2 0 1 0}$ & $\mathbf{2 0 1 1}$ & $\mathbf{2 0 1 2}$ & $\mathbf{2 0 1 3}$ & $\mathbf{2 0 1 4}$ & $\mathbf{2 0 1 5}$ & $\mathbf{2 0 1 6}$ \\
\hline Number of employees & 7,855 & 9,038 & 10,656 & 13,535 & 17,712 & 26,566 & 26,229 \\
\hline Number of passengers (m) & 7.1 & 8.3 & 10.2 & 11.5 & 14.8 & 17.6 & 18.4 \\
\hline Number of aircraft (at year end) & 57 & 64 & 70 & 89 & 110 & 121 & 119 \\
\hline
\end{tabular}




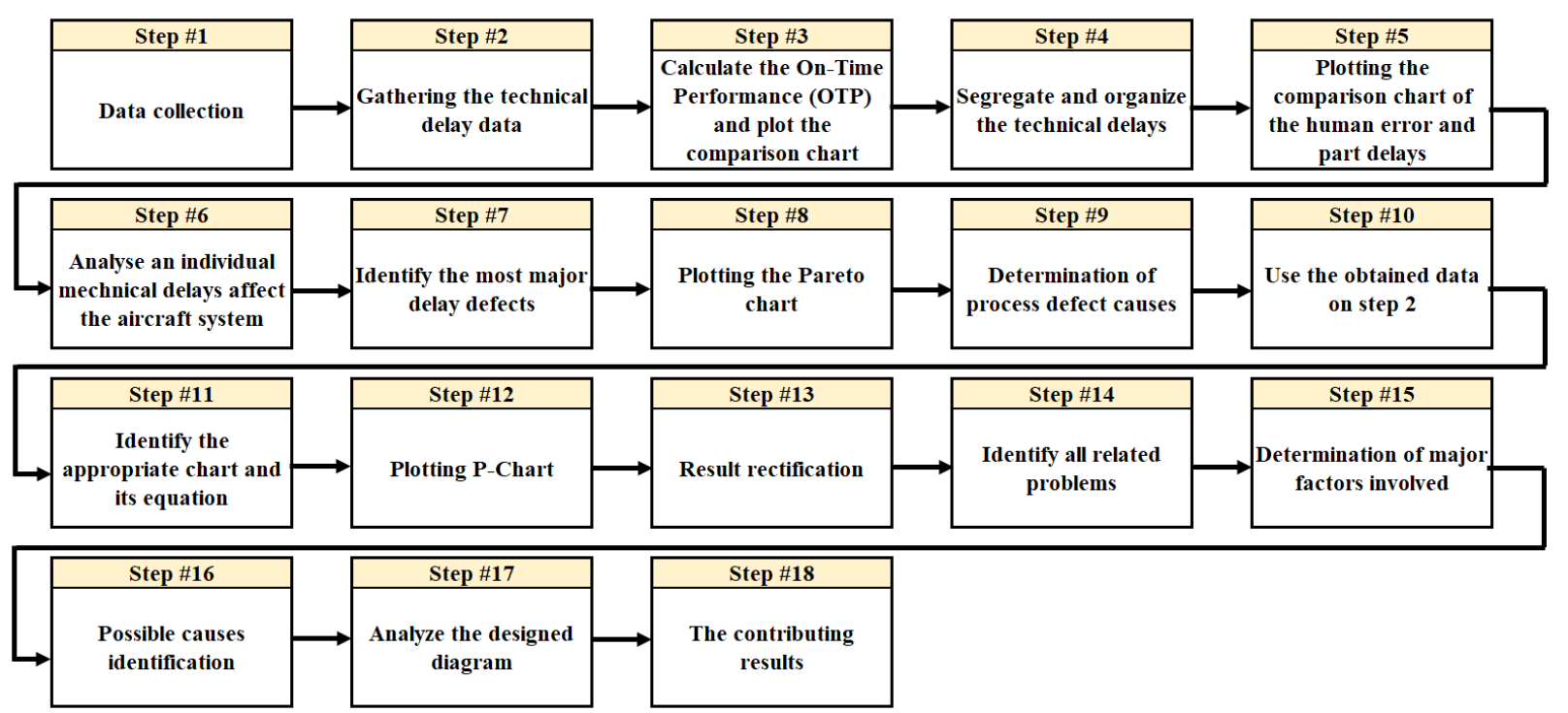

Fig. 1. The proposed model steps for QC implementation.

Table 5. Partial of On-Time Performance Data for the duration from Feb. 2016 to Jan. 2017.

\begin{tabular}{|c|c|c|c|c|c|c|}
\hline Month & $\begin{array}{c}\text { Flight } \\
\text { Hours }\end{array}$ & $\begin{array}{c}\text { Flight } \\
\text { Cycle }\end{array}$ & $\begin{array}{c}\text { Revenue } \\
\text { Departures } \\
\text { Cycle }\end{array}$ & $\begin{array}{c}\text { No. of Technical } \\
\text { Delays }\end{array}$ & $\begin{array}{c}\text { Delay } \\
\text { Rate \% }\end{array}$ & $\begin{array}{c}\text { OTP } \\
\text { Technical } \\
\text { Delays \% }\end{array}$ \\
\hline Feb-2016 & 3205 & 1244 & 1242 & 36 & 2.90 & 97.10 \\
Mar-2016 & 3353 & 1263 & 1257 & 88 & 7.00 & 93.00 \\
Apr-2016 & 3243 & 1192 & 1188 & 96 & 8.08 & 91.92 \\
May-2016 & 3271 & 1222 & 1218 & 96 & 7.88 & 92.12 \\
Jun-2016 & 3082 & 1182 & 1175 & 52 & 4.43 & 95.57 \\
Jul-2016 & 3524 & 1299 & 1291 & 56 & 4.34 & 95.66 \\
Aug-2016 & 3471 & 1341 & 1329 & 76 & 5.72 & 94.28 \\
Sep-2016 & 3730 & 1422 & 1397 & 68 & 4.87 & 95.13 \\
Oct-2016 & 3935 & 1713 & 1702 & 75 & 4.41 & 95.59 \\
Nov-2016 & 4365 & 1817 & 1805 & 72 & 3.99 & 96.01 \\
Dec-2016 & 5115 & 2259 & 2247 & 77 & 3.43 & 96.57 \\
Jan-2017 & 5232 & 2199 & 2173 & 96 & 4.42 & 95.58 \\
\hline
\end{tabular}

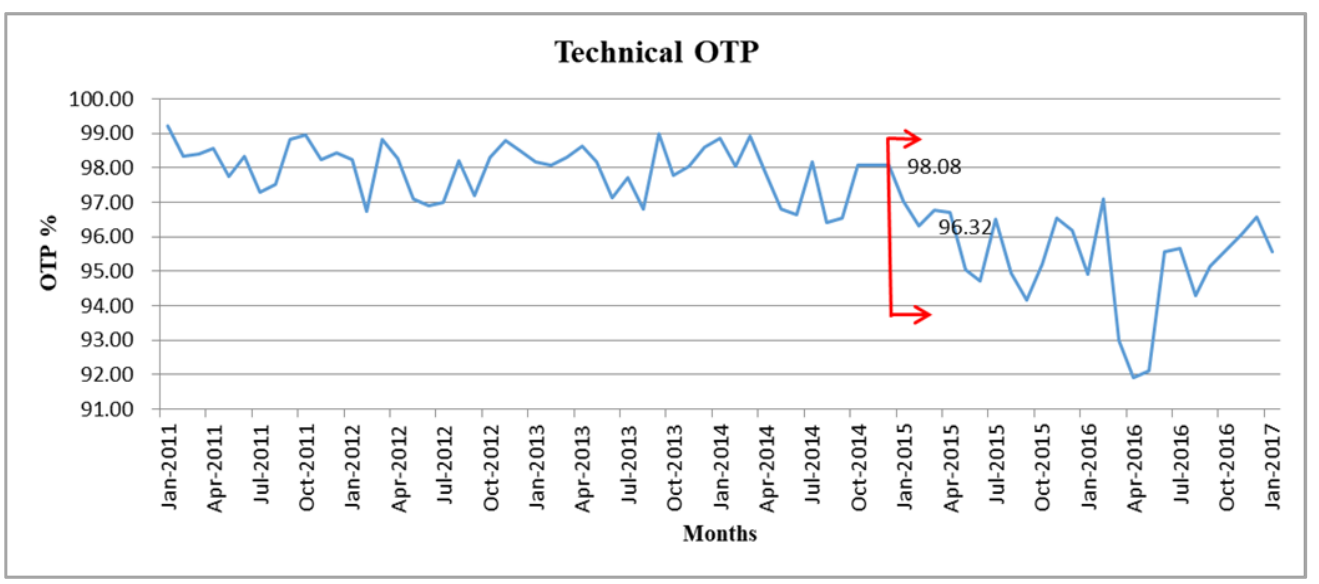

Fig. 2. The Technical OTP from Jan. 2011 to Jan. 2017. 
Next analysis steps will be taken through the technical delays which is consist of three types of delays which are:

- Mechanical delays.

- Human Error delays.

- Part delays.

\subsubsection{Steps (6-9): Data Analysis for Pareto Chart Tool}

The data analysis of Pareto chart tool identifies the mechanical delays that affect the OTP on aircraft. Each major delay will be considered on study in order to find the root causes that could assist for tackling the increasing of such delays.

\subsubsection{Steps (10-13): Data Analysis for Control Chart Tool}

The data analysis of control chart tool determines the causes of technical delays discrepancy in certain period. The technical delays will be under monitoring on monthly basis to observe process behavior over the year. The control chart represents this data and shows whether the process is in control or out of control due to assignable reasons. The unusual delays trend noticed on the chart outside the desired limits needs to be investigated in order solve it in ahead to improve the OTP.

Many types of Control Charts can be used depend on the data provided and the goals from the study, therefore to select the right control chart some figures should be taken into consideration In this paper the data used for counting the delays defected on the revenue departure per month, and the study been done for 12 months.

\subsubsection{Steps (14-17): Data Analysis for Fishbone Tool}

Through the findings on the two models performed on the study, which are the Pareto chart and the P-Chart; the fishbone comes to cover the related causes and effect that can be shared and presented to discuss it internally to find solution to improve the OTP in maintenance sector as at Saudi Airlines. Assigning group from different department sharing the concern in the company and brainstorming all the available ideas help to identify the possible causes related to the technical delays defect and to focus on the obstacles affecting this case regardless for any further unrelated issues on the company. The group consists of eight employees from the Engineering, Planning, Production, Procurement, Stores, Shipping, Aircraft on Ground (AOG) Desk and Shop departments. The step 18 given in Fig. 1 leads to the appropriate solutions to raise the performance rate of OTP.

\section{The Implementation of the Proposed QC Techniques}

\subsection{Implementation of Pareto Chart Tool}

By identifying the frequency of the major mechanical delays' defects that influence on the aircraft system per the Air Transport Association (ATA) chapter, which is a common referencing standard for commercial aircraft documentation for aircraft system, Table 6 describes the top ten ranked of ATA system and the cumulative percentage for each delay code. The Pareto chart given in Fig. 3 is plotted from the data given in Table 6.

Table 6. The Cumulative percentage of Top 10 Mechanical Delays.

\begin{tabular}{|c|l|c|c|}
\hline $\begin{array}{c}\text { Seq } \\
\#\end{array}$ & \multicolumn{1}{|c|}{ ATA } & $\begin{array}{c}\text { No. of } \\
\text { Delays }\end{array}$ & $\begin{array}{c}\text { Cumulative } \\
\%\end{array}$ \\
\hline 1 & 32-Landing Gear & 59 & $19 \%$ \\
2 & 25-Cabin & 45 & $33 \%$ \\
3 & 52-Doors & 41 & $46 \%$ \\
4 & 27-Flight Controls & 38 & $58 \%$ \\
5 & 28-Fuel & 33 & $68 \%$ \\
& 21-Air & & $76 \%$ \\
6 & Conditioning & 25 & \\
& 24-Electrical & & $83 \%$ \\
7 & Power & 21 & $89 \%$ \\
8 & 49-APU & 20 & $95 \%$ \\
9 & 38-Water/Waste & 17 & $100 \%$ \\
10 & 78-EngineExsaust & 17 & \\
\hline
\end{tabular}


The delay related to the landing gear system plays a big role to affect about $20 \%$ of the total mechanical delays. The first sixth ATA chapter are almost about $80 \%$ of the rank. However, Pareto chart gives a good scale to take the opportunity to focus on the major system problem and to lower the amount of delays by $46 \%$. From engineering technical points, the first five ATA system chapter are independent system and not interfering to each other, which those system were analyzed to find the root causes for each to improve them as much as can. The top five ATA problems and corrective/preventive action been taken for resolving or enhancing the technical review program as shown in Table 7.

\subsection{Implementation of P-Chart Control Tool}

Here, the data used for counting the delays defected on the revenue departure per months, and the study been done for 12 months. However, the suitable control chart is P-Chart because the delay is variable, and number of the revenue flight varies from day to day. In addition, the SAUDIA looks for the number of defective unit which is the delay on each revenue departure. To determine the p-chart formulas and in the beginning need to select all the input needed to plot the chart which is as follows:

- Let $n_{\mathrm{i}}$ is the sample size for month $\mathrm{i}$ and $\mathrm{i}=1, \ldots, \mathrm{K}$. Also, let $D_{i}$ represent the number of nonconforming units in the $i^{\text {th }}$ sample.

- $\mathrm{K}=12$

- Sample Size (ni) = Total Revenue departure for each month.

- $n_{1}=1242$ Revenue departure for Feb-16.

- Number of nonconforming units $(D)=$ Technical Delay every month.

- $D_{1}=36$ Technical Delay for Feb-16.

- $\operatorname{Sigma} \operatorname{Limit}(\mathrm{Z})=3$
From the calculated data in Table $8 \&$ Fig. 4 shows the technical delays proportion through the 12 months from Feb-2016 to Jan2017, three points are trend and out of the limit which is the period from Mar-2016 to May-2016 and one unstable point in Aug2016.

There are two points are indicated below the lower control limit. Delays target is to be zero therefore the delay below the lower limit is not acceptable. However, in Fig. 5 the lower control limit will be zero in order to reach to full revenue flight and raise the standard of the OTP.

The defected delays points fall out the upper control limit or control limit will be taken into consideration on this study. The control chart indicated three major points. Those points have been checked and evaluated to determine the special cause might occurred during these occasions as explained in Table 9.

Revaluation of the upper control limit months revealed that there are some reasons for increasing the delays in the assigned period, engineering and maintenance department should figure out the appropriate solution to solve them:

- History item causes many repeated delays 32, 21 and 24.

- MEL deferral till last minute.

- Many Equipment were Shortage in this period which lead aircraft delayed.

- Many parts are stock depleted.

- Oxygen modification raised as engineering order, but maintenance didn't follow the instruction properly

- Not following the right reference in the aircraft Log Book. 
- Some emergency equipment is expired and didn't check previously.

\subsection{Implementation of Fishbone Tool}

As demonstrated before both of Pareto chart and P-Chart are applied to identify the significant issues and problems facing the maintenance sector, as well any matters impacting the technical delays. The mechanical delays are important because it represents most of the technical delays. On other hand parts and human error delays cannot be ignored and should be involved in this investigation.

The Technical delays on this period were clearly increased in the two models of the Pareto chart and the control chart due to different reasons which can be gathered as given in table 10. The fishbone diagram is sued taking into considerations the following major factors:

- The Process: Any action should be taken from the maintenance and the other related departments before aircraft arrive/dispatch or influence for aircraft delays.
- Materials: Supply chain is responsible for offering a sufficient spare for all categories of aircraft parts specially the routine and emergency parts to handle the aircraft operation smoothly.

- People: All the maintenance personnel, engineers and planners either they work direct to aircraft or they assist for flight operation.

- Equipment: The tools used for handling the aircraft or supporting the mechanic for job task.

- Environment: The environment surrounded the maintenance company could defect the airplane or the employees in the workplace.

The assigned group from maintenance sector was committed to draw the fishbone diagram as portrayed in Fig. 6.

The constructed fishbone diagram, with its five major factors and their related elements, helped SAUDIA for improving the OTP as shown in Table 11.

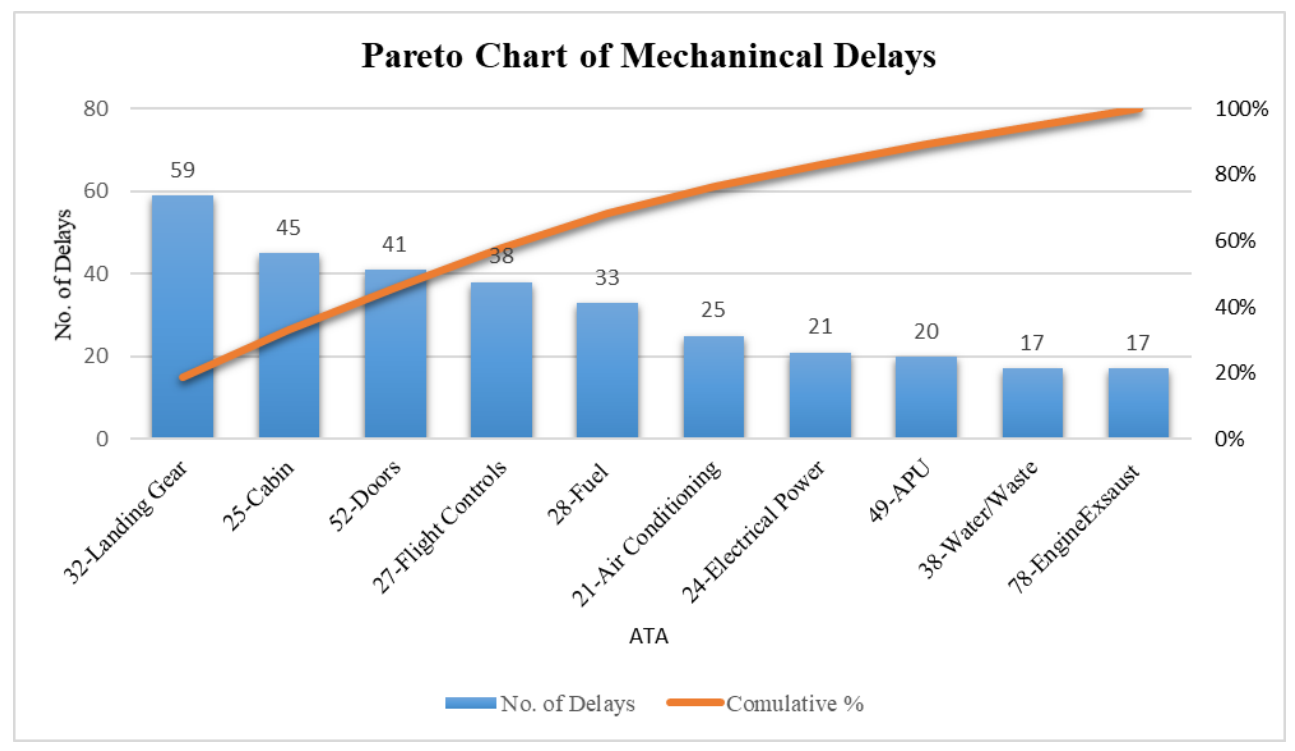

Fig. 3. Pareto Chart of Mechanical Delays. 
Table 7. Mechanical Delays Corrective Action.

\begin{tabular}{|c|c|c|}
\hline ATA & Delay Description & Corrective Action \\
\hline $\begin{array}{l}\text { 32- } \\
\text { Landing } \\
\text { Gear }\end{array}$ & $\begin{array}{l}\text { Low Tire Pressure. } \\
\text { Nose Landing Gear Vibration. } \\
\text { Landing Gear } \quad \text { Control } \\
\text { Interference Unit } \quad \text { (LGCIU) } \\
\text { Fault. }\end{array}$ & $\begin{array}{l}\text { Follow the Aircraft Maintenance Manual. } \\
\text { Whenever replace the NLG tire replace the other one. } \\
\text { Vendor recommends Keeping NLG shock absorber servicing within the } \\
\text { AMM limits. } \\
\text { New modification will be implemented to enhance the LGCIU. }\end{array}$ \\
\hline $\begin{array}{l}25- \\
\text { Cabin }\end{array}$ & $\begin{array}{l}\text { Mechanical Failure on business } \\
\& \text { Economy Class Seat. } \\
\text { Cabin appearance. }\end{array}$ & $\begin{array}{l}\text { Enhance the maintenance program for General Visual Inspection (GVI) } \\
\text { seat at every ISC, GVI and operate seat at every (A-check), Deep Visual } \\
\text { Inspection (DVI) seat at every (C-check). } \\
\text { Training has been accomplished to enhance the troubleshooting of the } \\
\text { Enhanced Power Supply. } \\
\text { Maintenance Service Letter issued to enhance trouble shooting of } \\
\text { Business class seats to reduce the number of unconfirmed failure related } \\
\text { to Enhance Power Supply. } \\
\text { Multi Cabin Items Missing, Increase the store quantity. }\end{array}$ \\
\hline $\begin{array}{l}52- \\
\text { Doors }\end{array}$ & $\begin{array}{l}\text { Door Indication Shows Door } \\
\text { Open While Door Closed. } \\
\text { AFT Cargo Indication Flag } \\
\text { Missing. } \\
\text { Cargo Door Handle. } \\
\text { Cargo Door ECAM Message } \\
\text { Comes During Climb. }\end{array}$ & $\begin{array}{l}\text { Add Corrective Action Proposal to PAX \& SRVC door sensor (12MJ } \\
\& 13 \mathrm{MJ}) \text { and target cleaning every } 1000 \mathrm{FH} \text {. } \\
\text { Engineering Document Issued to inspect and adjust flag indicator. } \\
\text { Maintenance Program for lubrication of hinge arm bearings and of } \\
\text { locking -, latching - and interlock mechanism. every } 24 \text { months, last } \\
\text { Maintenance program to perform operational check of door warning } \\
\text { system every 72Months. } \\
\text { Maintenance program to perform functional check of door every } 72 \\
\text { Months }\end{array}$ \\
\hline $\begin{array}{l}27- \\
\text { Flight } \\
\text { Controls }\end{array}$ & $\begin{array}{l}\text { Slat / Flat Fault } \\
\text { Flight Control Primary } \\
\text { Computer Fault } \\
\text { Flight Control Sensor Fault }\end{array}$ & $\begin{array}{l}\text { Modification has been complied to introduce new software \& hardware } \\
\text { for more operation stability. } \\
\text { Modification to introduce new software to reduce the spurious MSG and } \\
\text { transit fault. } \\
\text { Fleet camping issued to inspect/check the transducer sensor with NIL } \\
\text { finding. }\end{array}$ \\
\hline 28-Fuel & $\begin{array}{l}\text { Single Motor Actuator. } \\
\text { Fuel Drain Valve. } \\
\text { Spurious Messages. }\end{array}$ & $\begin{array}{l}\text { Modification has been complied to exchange program for the improved } \\
\text { part. } \\
\text { Maintenance service Letter to inform Maintenance to use Special Tool } \\
\text { during Sump and Drain procedure as per AMM Manual to prevent Fuel } \\
\text { Leak after Sump and Drain process. } \\
\text { S/W modification has been complied with to clear this message. }\end{array}$ \\
\hline
\end{tabular}

Table 8. P-Chart of A330 Flight Delay Proportion.

\begin{tabular}{|c|c|c|c|c|c|c|}
\hline Month & $\begin{array}{c}\text { Technical } \\
\text { Delays }\end{array}$ & $\begin{array}{c}\text { Revenue } \\
\text { Departure } \\
\text { Cycle }\end{array}$ & $\begin{array}{c}\text { Delay } \\
\text { Proportion(p) }\end{array}$ & CL (P) & UCL & LCL \\
\hline Feb-2016 & 36 & 1242 & 0.029 & 0.049 & 0.068 & 0.031 \\
Mar-2016 & 88 & 1257 & 0.070 & 0.049 & 0.068 & 0.031 \\
Apr-2016 & 96 & 1188 & 0.081 & 0.049 & 0.068 & 0.030 \\
May-2016 & 96 & 1218 & 0.079 & 0.049 & 0.068 & 0.031 \\
Jun-2016 & 52 & 1175 & 0.044 & 0.049 & 0.068 & 0.030 \\
Jul-2016 & 56 & 1291 & 0.043 & 0.049 & 0.067 & 0.031 \\
Aug-2016 & 76 & 1329 & 0.057 & 0.049 & 0.067 & 0.031 \\
Sep-2016 & 68 & 1397 & 0.049 & 0.049 & 0.067 & 0.032 \\
Oct-2016 & 75 & 1702 & 0.044 & 0.049 & 0.065 & 0.033 \\
Nov-2016 & 71 & 1805 & 0.039 & 0.049 & 0.064 & 0.034 \\
Dec-2016 & 77 & 2247 & 0.034 & 0.049 & 0.063 & 0.036 \\
Jan-2017 & 96 & 2173 & 0.044 & 0.049 & 0.063 & 0.035 \\
\hline
\end{tabular}




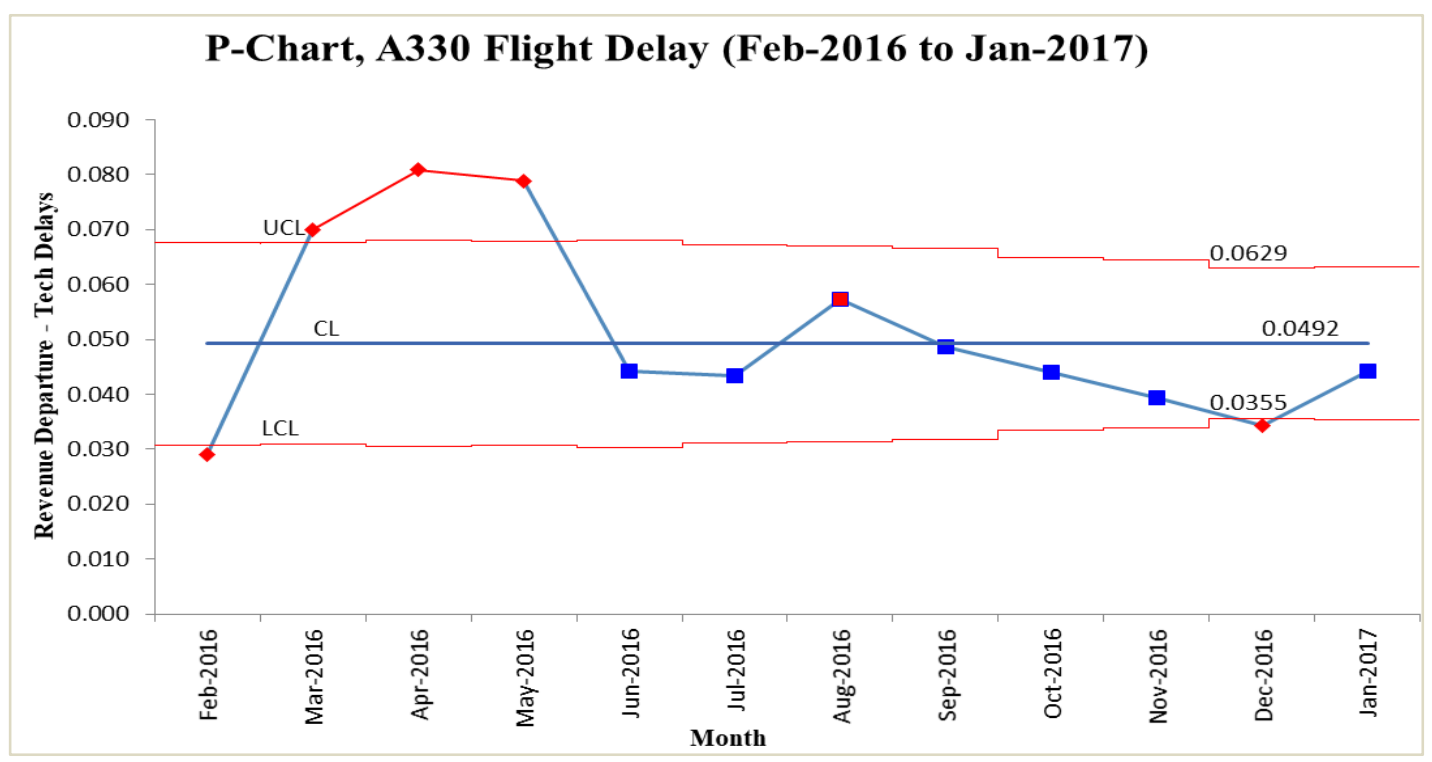

Fig. 4. P-Chart, A330 flight Delay (Feb-2016 to Jan-2017).

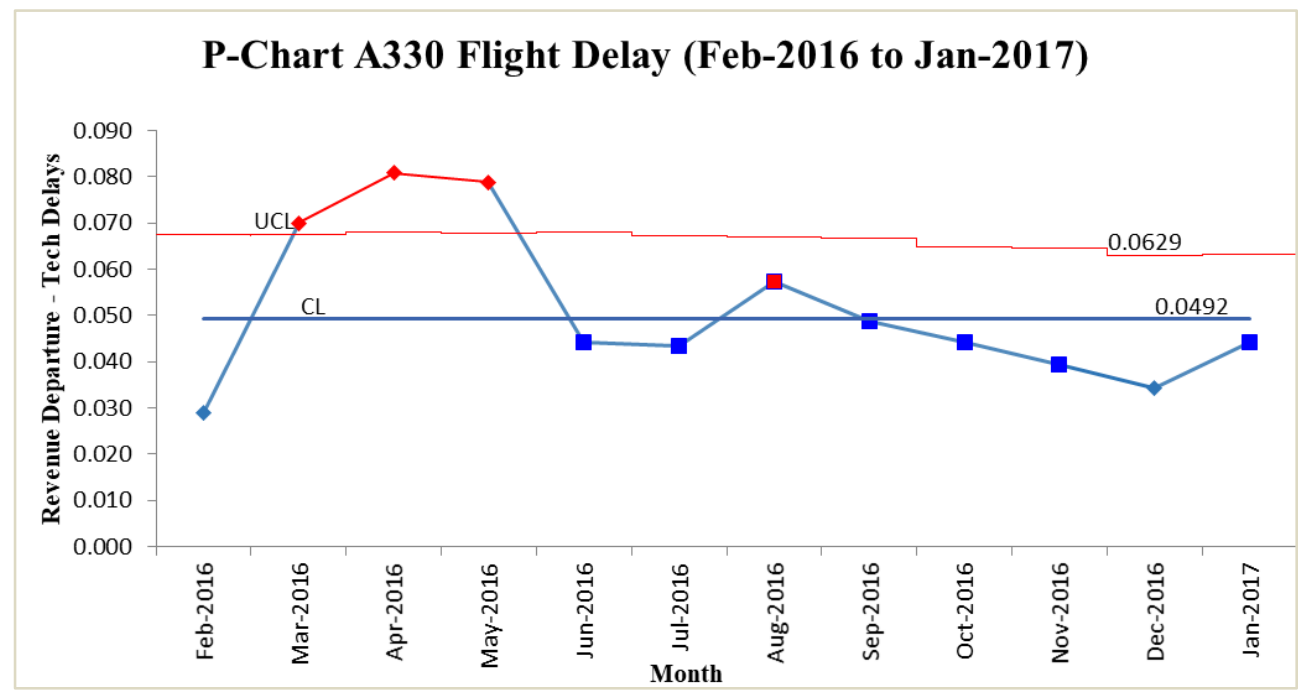

Fig. 5. P-Chart, A330 flight Delay (Feb-2016 to Jan-2017) LCL.

Table 9. The lowest Technical delays from Feb-2016 to May-2016.

\begin{tabular}{|c|c|c|c|c|c|}
\hline Month & $\begin{array}{c}\text { No. of } \\
\text { Mechanical } \\
\text { Delay }\end{array}$ & $\begin{array}{c}\text { No. of Part } \\
\text { Delay }\end{array}$ & $\begin{array}{c}\text { No. of Human } \\
\text { Error Delay }\end{array}$ & $\begin{array}{c}\text { No. of Technical } \\
\text { Delays }\end{array}$ & $\begin{array}{c}\text { Technical } \\
\text { OTP \% }\end{array}$ \\
\hline Mar-2016 & 62 & 13 & 13 & 88 & 93.00 \\
Apr-2016 & 72 & 7 & 17 & 96 & 91.92 \\
May-2016 & 57 & 15 & 24 & 96 & 92.12 \\
\hline
\end{tabular}


Table 10. Technical Delays Causes.

\begin{tabular}{|l|l|}
\hline Delay Type & Delay Causes Description \\
\hline Mechanical & - History item causes many repeated delays. \\
& - Modification has not complied with. \\
& - Troubleshooting of some aircraft not properly resolved which causes flight cancelation. \\
& - Solving aircraft failure by improper replacing part which disturb aircraft next visit.
\end{tabular}

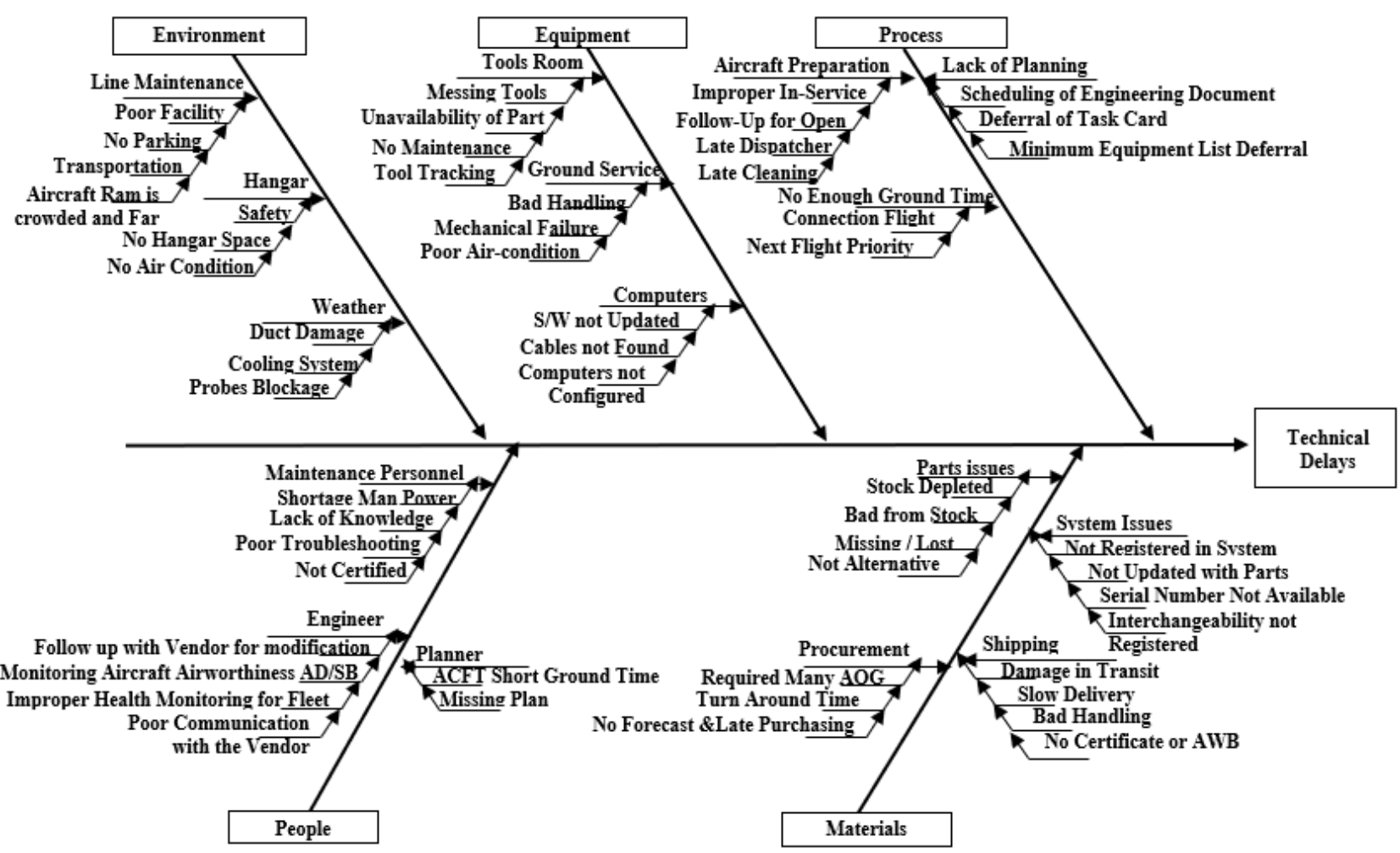

Fig. 6. Fishbone of A330 Technical Delays. 
Table 11. Part and Human Errors Delays Solution.

\begin{tabular}{|c|c|c|}
\hline Major Factor & Problems & Solutions \\
\hline Process & $\begin{array}{l}\text { - Improper in-service check. } \\
\text { - Follow up for open Work order. } \\
\text { - Minimum equipment list deferral. }\end{array}$ & $\begin{array}{l}\text { - Quality department involved for investigation. } \\
\text { - Aircraft Review Monitoring (ARM) meeting conducted to } \\
\text { follow up the open work order and to plan the MEL defect. }\end{array}$ \\
\hline Materials & $\begin{array}{l}\text { - Stock Depleted. } \\
\text { - Many AOG part. } \\
\text { - Not Registered in the System. }\end{array}$ & $\begin{array}{l}\text { - Increasing the part stock quantity. } \\
\text { - Conducting the Aircraft Review Meeting and discuss the } \\
\text { part required. } \\
\text { - Engineering updated the system for parts. }\end{array}$ \\
\hline Equipment & $\begin{array}{l}\text { - Unavailability of tools. } \\
\text { - No Maintenance Program. } \\
\text { - Tools Tracking. }\end{array}$ & $\begin{array}{l}\text { - Counting the operational equipment and fixed the } \\
\text { inoperative. } \\
\text { - Listed all missing tools and order it. } \\
\text { - Signing sheet to track the tools by employee number. } \\
\text { - Scheduling maintenance program for tools. } \\
\text { - Instruct Quality department to perform periodic inspection. }\end{array}$ \\
\hline Environment & $\begin{array}{l}\text { - No Hangar Space. } \\
\text { - Probe Blockage. } \\
\text { - Transportation. }\end{array}$ & $\begin{array}{l}\text { - Still in progress. } \\
\text { - Maintenance program issued for visual inspection. } \\
\text { - Provided more buses. }\end{array}$ \\
\hline People & $\begin{array}{l}\text { - Improper Heath Monitoring. } \\
\text { - Poor Troubleshooting. } \\
\text { - Lack of Knowledge for New Hire. }\end{array}$ & $\begin{array}{l}\text { - Group assigned from Engineering and MCC. } \\
\text { - Maintenance Service Letter normally issue to instruct } \\
\text { maintenance personnel. } \\
\text { - New Training Program conducted for new hire. }\end{array}$ \\
\hline
\end{tabular}

\section{Results and Discussions}

In order to proof the feasible solution and to have more result validation, application been done during the 2017 to do comparison for the improvement of the OnTime Performance and the delays record. Figure 7 presents the on-time performance of year 2017. The figure shows an improvement on the OTP which has approximately $96 \%$ on average, and the range of the OTP from $93.93 \%$ to $97.66 \%$. For further clarification Fig. 8 presents the OTP in year 2016 compared with that on year 2017.

Despite the increasing of aircraft fleet on 2017, the OTP keeps rising and show better indication in 2017. The OTP increased from $94.75 \%$ to $96.01 \%$. This improvement supposed to be reflected on the mechanical delays as the major improvement and progress was done by implementing the modification for enhancement the most ATA system problems to avoid delays counting. Figure 9 presents the top ten ranked system on 2017 and compare it with 2016.
Some ATA systems were not in top ten ranked in 2016 and some are gone. This drives that in some conditions the fleet can be affected if there is a mechanical failure or operational issue. Moreover, the figure shows how is the top five systems have been corrected in 2016 made some reduction on all system except the landing gear (32), which has the low-pressure problem still not solved and might be need more effort to contact the vendor, also, there is a new issues related to nose landing gear vibration discovered lately in the new aircraft, as per below Table 12 shows the improvement on the mechanical delays.

The number of delays in ATA 32 shows in 2017 double the number of delays in 2016, but the delays rate not much changed this because the delay rate depends on the revenue departure cycle which is 35,320 flight cycles in 2017 but in 2016 is 18,024 flight cycles. Figure 10 presents the utilization trend 2016 till end of 2017 and how many A330 fleet becomes. 


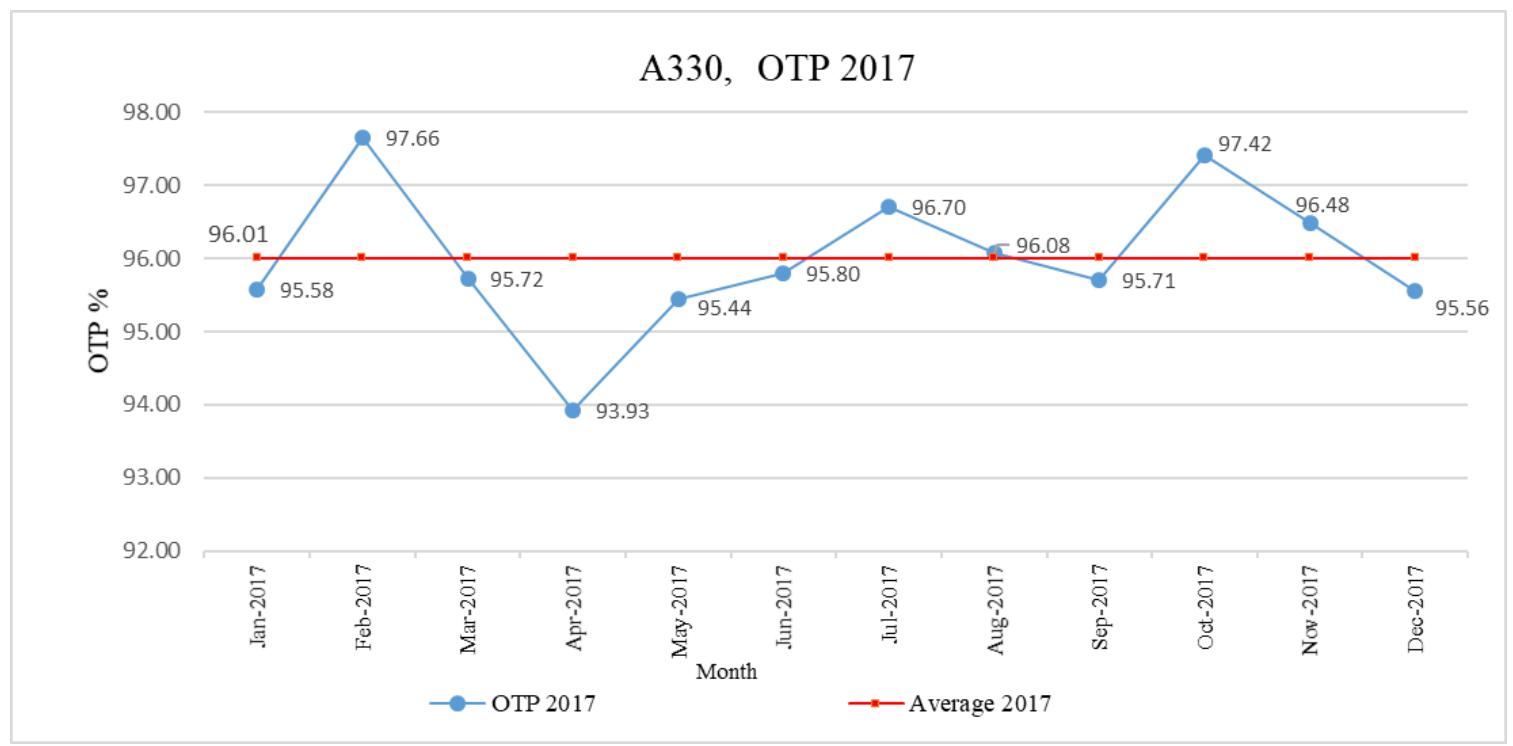

Fig. 7. A330 On Time Performance 2017.

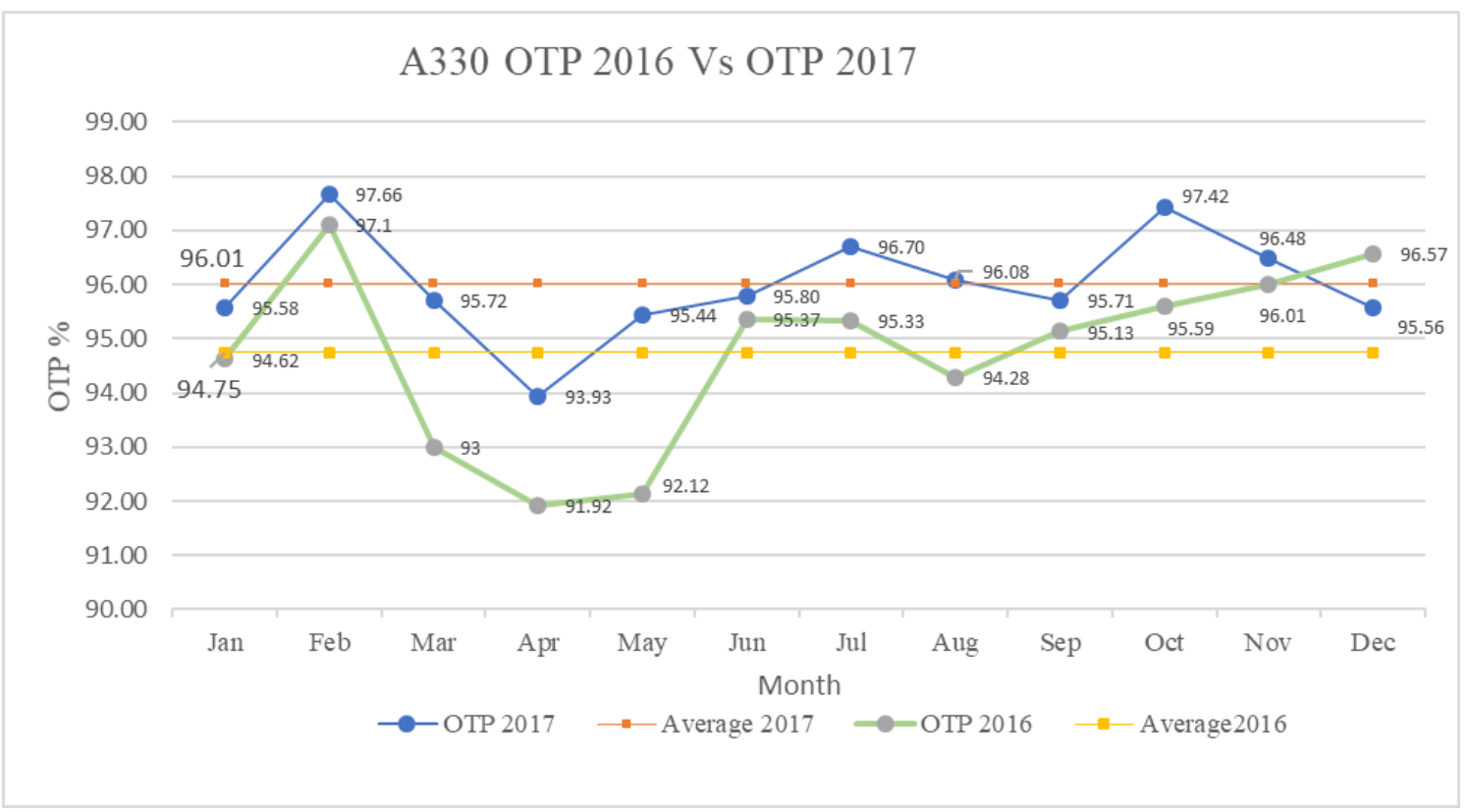

Fig. 8. A330 OTP 2016 \& 2017. 


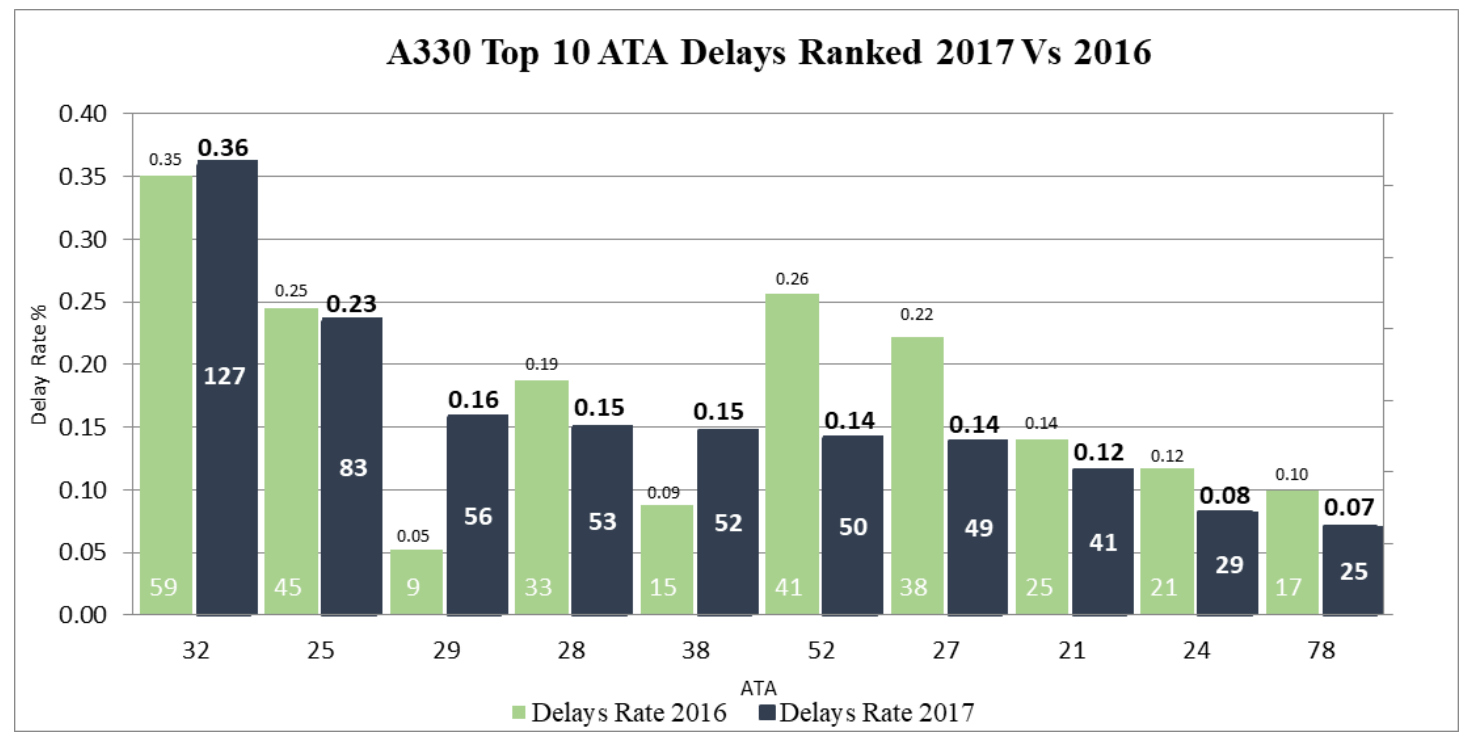

Fig. 9. Mechanical Delays Ranked by Top 10 (2017 VS 2016).

Table 12. Delay Rates in 2017.

\begin{tabular}{|l|c|c|}
\hline \multicolumn{1}{|c|}{ ATA } & Delays Rates \% 2016 & Delays Rates \% 2017 \\
\hline 32-Landing Gear & 0.35 & 0.36 \\
\hline 25-Cabin & 0.25 & 0.23 \\
\hline 52-Doors & 0.26 & 0.14 \\
\hline 27-Flight Controls & 0.22 & 0.14 \\
\hline 28-Fuel & 0.19 & 0.15 \\
\hline
\end{tabular}

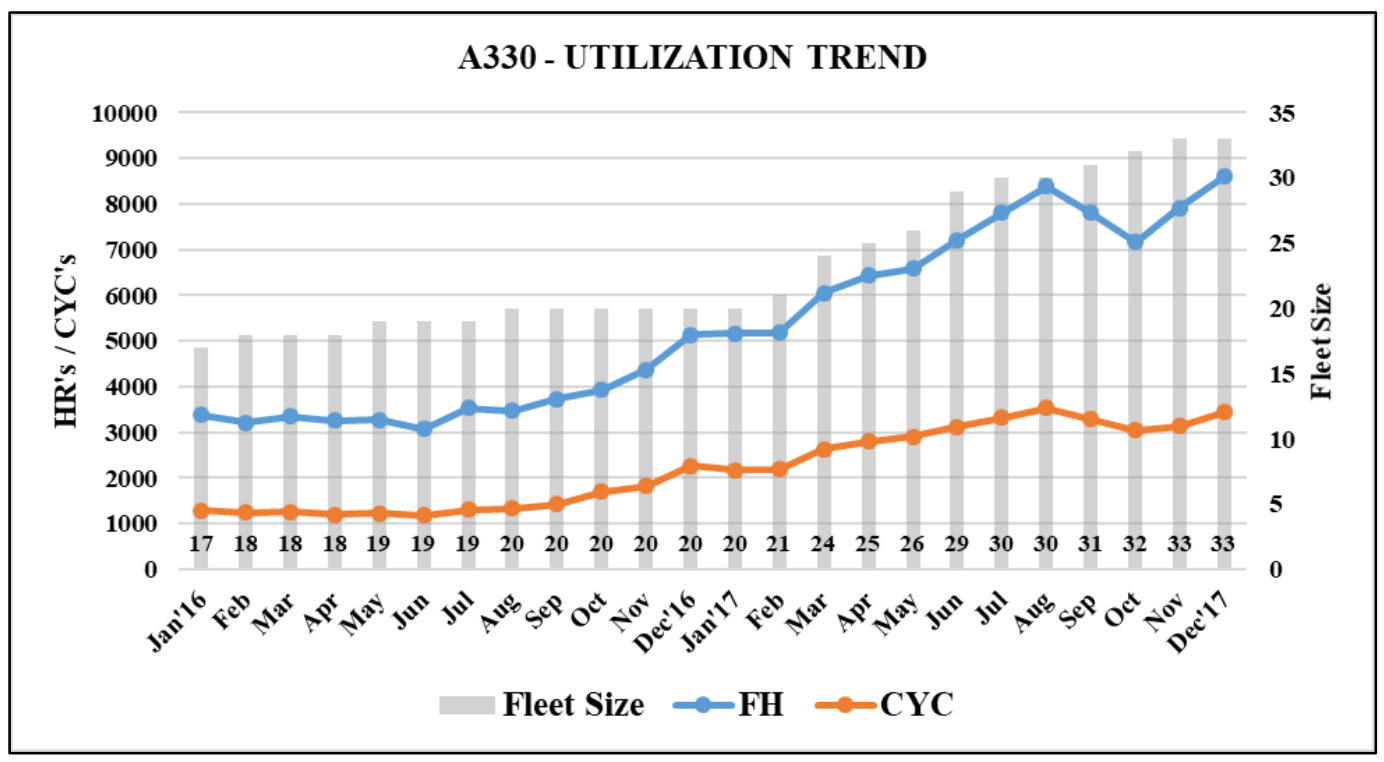

Fig. 10. A330 Utilization Trend. 


\section{Recommendations}

The quality controls tools used, in this paper, are the Pareto chart, Control chart and the Fishbone diagram. They overcame the most obstacles and problems faced the maintenance sector at Saudi Airlines Company as compared with the results of year 2016. It presented high improvement reflects on the results and solutions provided for the OTP study.

From the results obtained on the maintenance sector, it is recommended to implement the Total Quality Management (TQM) in the rest of maintenance departments in the sector and consider the quality control tools one of the requirement function to determine the delays defects. In other words, the following recommendations are proposed to enhance the application of TQM:

- Reviewing and studding all mechanical delays occurred during the day and report them by the assigned engineer to find the root causes in order to investigate them with the vendor for modification. This should be done on daily basis to have good data bank at the end of year.

- Conducting a technical review meeting every quarter discuss all delays causes, the failures and the obstacles faces during the certain time to end up with the valuable findings or solution can be resolved in next quarter meetings.

\section{- Technical Quality Assurance} department should be more restrictive with maintenance by issuing the necessary penalties for any idleness or neglect may occur, in order to comply with safety procedures and to maintain the safety of passengers. as the mechanics are the life blood of business and it is essential for the company to motivate them and keep them on right track. They should undertake thorough training campaign to motivate them and train them in proper way. Coordination among all the employees also needed to be done and it also require specifying about their individual responsibilities.

- Use a special automated program for implementing control chart by integrating the dedicated program with Saudi data system to take the data and detect the delays automatically.

- Conduct at least three workshops annually to have about two members of each department to do the brainstorming to reach to common major issues causes the delays, take the majority and the common issues and discuss them with the top management to find a proper and quick solution.

- Enhance the maintenance system to include the part tracking for the tools department, it also should be requested by the user in order to eliminate the tooling missing and to be carefully handled.

- Most airlines companies in the worldwide have a pool agreement for A330 fleet for providing the routable parts whenever they need, this will offer appropriate spares for SAUDIA.

\subsection{Future Researches}

- This study can be extended to include the all airlines fleets to compare them together to have the major common issues could affect the fleet. This kind of research will focus on the most common issues can be handled and raise it to the top management for quick response.

- For the departments that shared the responsibility of causing delays, they need to use the TQM to solve the internal problems and find the root causes on their department such as the supply chain to solve the stock 
depleted and the other related issues, or the store department to solve the shipping handling issues.

\section{References}

[1] De Felice F., Petrillo A. and Silvestri, A. (2012). Multi-Criteria risk analysis to improve safety in manufacturing systems. International Journal of Production Research, 50 (17) : 4806- 4822.

[2] Jay, H. and Barry, R. (2008). Principles of Operations management. 7th ed. New Jersey: Pearson Prentice Hall, Inc.

[3] McQuater, R.E., Scurr, C.H., Dale, B.G. and Hillman, P.G. (1988). Using quality tools and techniques successfully. The TQM Magazine, 7(6): 3742.

[4] Juran, J. M. and Gryna, F,M. (1988). Juran's Quality Control Handbook, McGraw-Hill book company New York, NY.

[5] Paliska, G., Pavletic, D. and Sovic, M. (2007). Quality tools-systematic use in process Industry.
Journal of Achievement in Materials and Manufacturing Engineering. 25(11): 79- 82.

[6] Fouad, R.H. and Mukattash, A. (2010). Statistical process control tools: A practical guide for Jordanian Industrial Organizations. JJMIE, 4(6): 693- 700.

[7] Gupta C. and Belokar M. (2012). Applications of Total Quality Management in Indian Airline Industry Pec University, Department of Production Engineering,Sector-12, Chandigarh 160012, India .

[8] Kelvin (2014). Etihad Airways Quality Management from: http://essayturf.com/blog/etihad-airways-qualitymanagement/ Access date: February 18, 2018.

[9] Ben Schlappig (2016). Etihad Airways Gets A Skytrax 5-Star Rating, from: http://onemileatatime.boardingarea.com/2016/10/13/eti had-5-star-skytrax/, Access date, February 18, 2018.

[10] Etihad Airways (2017). Etihad Airways reports, from: http://www.etihad.com/en-gb/about-us/etihadnews/archive/2017/, Access Date February 19, 2018.

[11] Montgomery, Douglas C. (2001). Introduction to Statistical Quality Control (4th Edition).New York: John Wiley \& Sons, Inc. 


\title{
استخدام أدوات ضبط الجودة لتعزيز الإنتاجية في قطاع صبانة طائرات الخطوط الجوية السعودية
}

\author{
عمر سالم باريود، و رضا محمد سعيد عبد العال، و محمد رضا كابلي \\ قسم الهندسة الصناعية، كلية العندسة، جامعة الملك عبد العزبز، جدة، المدلكة العربية السعودية \\ o.barboud@hotmail.com
}

المستخلص. لاحظت الشركة السعودية لصيانة الطائرات أن الأداء في الوقت المحدد لأسطولها من طائرات ايرباص • ATr قد انخفضت خلال الثناث السنوات الماضية، مما استذعى اكتشاف المشاكل التي واجهت الثركة في الفترة السابقة للحفاظ على مزايا الثركة التتافسية في سوق العمل، والتي تهدف للحد من تكاليف الصيانة وتعزيز الإنتاجية، من حيث تحسين نوع الخدمة المقدمة في الوقت المطلوب. لذلك فإن أحد الخطوات المهمة للحصول على الأهداف السامية لهذه الدراسة، وهي تتفيذ أدوات مراقبة الجودة التي تأني بدورها لمعرفة الأسباب الجذرية

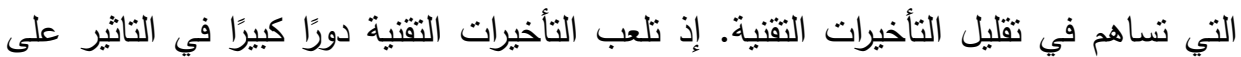
الأداء في الوقت المحدد، حيث أنها تتقسم إلى تأخيرات ميكانيكية، وتأخيرات أجزاء الطائرة، وتأخيرات الأخطاء البشرية. تقوم الدراسة بتطبيق ثلاث أدوات إحصائية لضبط وتحسين الجودة، وهي كالتالي، مخطط باريتو، ومراقبة الجودة، ومخطط هيكل السمكة. المخطط باريتو يستخدم

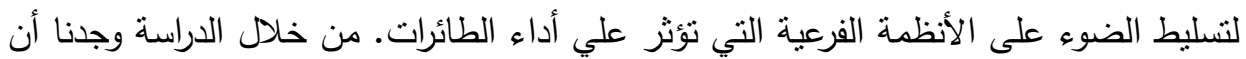
معظم الأنظمة هي معدات الهبوط، والأبواب، والمقصورة، والوقود، وأجهزة التحكم في التحليق. ملئ أما بالنسبة لمراقبة الجودة، فقد تبين خلال استخدام P-Chart أن هناك ثثلاث نقاط رئيسة في أثنهر مختلفة للتأخيرات التقنية، وتعد خارج حدود الرسم البياني، مما تحتاج إلى أخدها بعين الاعتبار للتقييم والتحقيق في أمرها والسعي وراء حلها. من خلال تطبيق الأدوات السابقة، نجد أن بعض المشاكل التي من خلالها تتم مناقتشها مع مختلف الأفراد والأقسام في قسم صيانة الطائرات، بحيث نصل إلى مرحلة العصف الذهني لجمع أكبر عدد من المشاكل ومواجنها بحلول قيمة تمنع حدوثها مره أخرى، ومما بيساعد على تتفيذ ذلك أداة هيكل السمكة. ساهمت

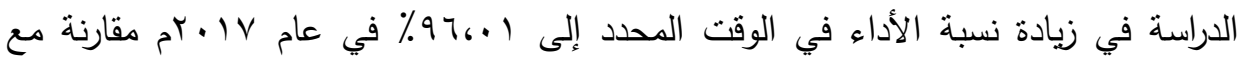

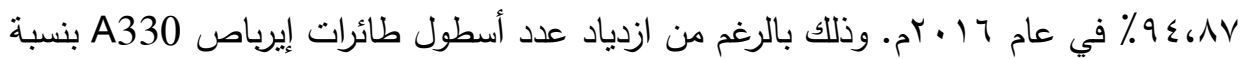

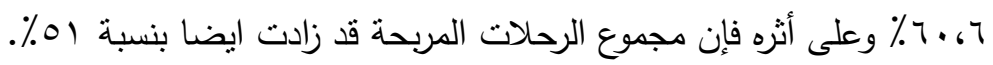

كلمات مفتاحية: أدوات ضبط الجودة، الأداء فى الوقت، صبانة الطائرات، التأخيرات الفنية، التأخيرات الميكانيكية. 
